University of Nebraska - Lincoln

DigitalCommons@University of Nebraska - Lincoln

USDA National Wildlife Research Center - Staff Publications
U.S. Department of Agriculture: Animal and Plant Health Inspection Service

2011

\title{
The Relative Abundance of Deer Mice with Antibody to Sin Nombre Virus Corresponds to the Occurrence of Hantavirus Pulmonary Syndrome in Nearby Humans
}

\author{
Charles H. Calisher \\ Colorado State University - Fort Collins, calisher@cybersafe.net \\ James N. Mills \\ U.S. Centers for Disease Control and Prevention \\ J. Jeffrey Root \\ USDA/APHIS/WS National Wildlife Research Center, jeff.root@aphis.usda.gov \\ Jeffrey B. Doty \\ Colorado State University - Fort Collins \\ Barry J. Beaty \\ Colorado State University - Fort Collins
}

Follow this and additional works at: https://digitalcommons.unl.edu/icwdm_usdanwrc

Calisher, Charles H.; Mills, James N.; Root, J. Jeffrey; Doty, Jeffrey B.; and Beaty, Barry J., "The Relative Abundance of Deer Mice with Antibody to Sin Nombre Virus Corresponds to the Occurrence of Hantavirus Pulmonary Syndrome in Nearby Humans" (2011). USDA National Wildlife Research Center - Staff Publications. 1355.

https://digitalcommons.unl.edu/icwdm_usdanwrc/1355

This Article is brought to you for free and open access by the U.S. Department of Agriculture: Animal and Plant Health Inspection Service at DigitalCommons@University of Nebraska - Lincoln. It has been accepted for inclusion in USDA National Wildlife Research Center - Staff Publications by an authorized administrator of DigitalCommons@University of Nebraska - Lincoln. 


\title{
The Relative Abundance of Deer Mice with Antibody to Sin Nombre Virus Corresponds to the Occurrence of Hantavirus Pulmonary Syndrome in Nearby Humans
}

\author{
Charles H. Calisher, James N. Mills, ${ }^{2}$ Jon Jeffrey Root, ${ }^{1, *}$ Jeffrey B. Doty,, and Barry J. Beaty ${ }^{1}$
}

\begin{abstract}
Sin Nombre virus (SNV) is the principal cause of hantavirus pulmonary syndrome (HPS) in the United States and deer mice (Peromyscus maniculatus) are its principal rodent host, and thus the natural cycle of the virus is related to the occurrence of HPS. Prevalence of rodent infection appears to be associated with fluctuations in deer mouse populations and, indirectly, with timing and amount of precipitation, a complex of biologic events. Given that rodent population abundances fluctuate, often acutely, it is not unreasonable to assume a direct correlation between the numbers of infected rodents and the number of human infections, unless confounding factors are involved. During a 13-year longitudinal study at a site in southwestern Colorado, we accumulated data regarding deer mice and antibody to SNV and therefore had the opportunity to compare dynamics of deer mouse populations, seroprevalence of antibody to SNV in the rodents, and numbers of HPS cases in Durango and in the State of Colorado as a whole. If abundances of deer mouse populations are directly correlated with occurrence of HPS, it is reasonable to assume that low densities of deer mice and low prevalences of antibody to SNV would lead to fewer human cases than would high densities and high prevalences. Our results substantiate such an assumption and suggest that the risk of acquisition of HPS is likely related to both high numbers of infected deer mice and human activities, rather than being strictly related to prevalence of SNV in the host rodent.
\end{abstract}

Key Words: Antibody prevalence-Deer mice-Hantavirus pulmonary syndrome-Peromyscus maniculatusPopulation abundance-Risk factors-Rodents—Sin Nombre virus.

\section{Introduction}

S IN Nombre virus (SNV; family Bunyaviridae, genus Hantavirus) is the principal cause of hantavirus pulmonary syndrome (HPS) in the United States (Hughes et al. 1993). Although several other hantaviruses have been identified here, each associated with rodents or shrews of other species, the great majority of HPS cases in North America are associated with SNV. The natural cycle of SNV is characterized by transmission principally between its primary rodent host, the deer mouse (Peromyscus maniculatus), and the epidemiology of HPS in North America is associated by complex means with the epizootiology of SNV in deer mice (Childs et al. 1994,
Yates et al. 2002). Infection of deer mice with SNV, as determined by the presence of antibody to the virus, has been shown to be negatively correlated with rodent species richness (Calisher et al. 2005), prevalence of antibody is higher in male than in female deer mice (Calisher et al. 1999), and deer mouse acquisition of SNV varies seasonally (Calisher et al. 1999). Long-lived infected deer mice serve as transseasonal reservoirs for the virus, providing a mechanism for its survival (Calisher et al. 2007). Prevalence of rodent infection appears to be associated with fluctuations in deer mouse populations and, indirectly, with timing and amount of precipitation; the resulting complex biologic events have been termed a bottom up "trophic cascade" (Yates et al. 2002).

\footnotetext{
${ }^{1}$ Arthropod-borne and Infectious Diseases Laboratory, Department of Microbiology, Immunology, and Pathology, College of Veterinary Medicine and Biomedical Sciences, Colorado State University, Fort Collins, Colorado.

${ }^{2}$ Special Pathogens Branch, Division of Viral and Rickettsial Diseases, National Center for Zoonotic, Vector-Borne, and Enteric Diseases, Coordinating Center for Infectious Diseases, U.S. Centers for Disease Control and Prevention, Atlanta, Georgia.

*Present address: U.S. Department of Agriculture, Wildlife Services, National Wildlife Research Center, Fort Collins, Colorado.
} 
Given that rodent population abundances fluctuate, often acutely, it is not unreasonable to assume a direct correlation between the sizes of rodent populations and the number of human infections, unless confounding factors are involved. During a 13-year longitudinal study at a site in southwestern Colorado, near the town of Durango (2005 population 15,500), we accumulated an extensive database regarding deer mice and antibody to SNV at that location (Calisher et al. 1999, 2007) and therefore had the opportunity to compare dynamics of deer mouse populations, seroprevalence of antibody to SNV in the rodents, as well as numbers of HPS cases in Durango and in the State of Colorado as a whole. If abundance of deer mice is directly correlated with occurrence of HPS, it is reasonable to assume that low abundances of deer mice and low prevalences of antibody to SNV would lead to fewer human cases than would high abundances and high prevalences. Our results substantiate such an assumption and suggest that the risk of acquisition of HPS is likely to be related to both high numbers of infected deer mice and human activities, rather than being strictly related to prevalence of SNV in the host rodent.

\section{Materials and Methods}

\section{Description of sites and trapping procedures}

The study area in Colorado, at Fort Lewis (La Plata County, southwest Colorado; N 37 $13^{\prime} 30.9^{\prime \prime}$ latitude, W 108 $10^{\prime} 51.1^{\prime \prime}$ longitude, elevation $2438 \mathrm{~m}$ ), initially was chosen because it is within a few kilometers of the original 1993 Colorado casepatient residences, $\sim 30 \mathrm{~km}$ distant from the town of Durango. The habitat at the Fort Lewis study site is montane shrubland (Fitzgerald et al. 1994) superimposed on intrusive igneous rocks forming laccoliths (Baars 1995). Vegetation is comprised predominantly of ponderosa pine (Pinus ponderosa), Gambel's oak (Quercus gambeli), sagebrush (Artemesia spp.), a variety of grama grasses (Bouteloua spp.), and many minor floral components.

We established trapping webs at two locations, as previously described in detail (Calisher et al. 1999). Briefly, 145 livetraps were set at the same locations at each of two webs beginning in June 1994 and trapped for three nights each 6 weeks for 13 years, except when precluded by winter conditions (usually November to March). Captured rodents were ear-tagged, processed (measured, identified to species and gender, and bled), and released at the exact sites of their captures. Only adult ( $\geq 17$ grams) deer mice were included in these analyses because antibody in younger deer mice might reflect the presence of maternal antibody, rather than their having been infected with SNV.

Trapping was not conducted every month and some months represented relatively small samples sizes, resulting in large month-to-month variations in numbers of captures, numbers of antibody-positive rodents, and prevalence. To normalize this variation and make seasonal patterns more discernible, we combined data from trapping sessions into quarterly values for graphical analysis. Quarters were defined as follows: 2 (spring) = April-June; 3 (summer) = July-September; 4 (autumn) = October-December. There was no trapping conducted in quarter 1 (winter, January-March).

\section{HPS diagnosis}

Human HPS cases were those clinically and serologically confirmed by the Disease Control and Environmental Epidemiology Division, Colorado Department of Public Health and Environment, Denver, and the Special Pathogens Branch, National Center for Infectious Diseases, U.S. Centers for Disease Control and Prevention, Atlanta, Georgia. Outside La Plata County, there were $42 \mathrm{SNV}$ infections of humans in Colorado, 1 with exposure to the virus in Arizona in 2000: 1 each in 1994, 1995, and 1996; 2 in 1997; 5 in 1998; 4 in 1999; 6 in 2000; 1 in 2002; 5 in 2003; 4 in 2004; 11 in 2005; and 6 in 2006 (data courtesy of Colorado Department of Health and Environment, Denver, and the U.S. Centers for Disease Control and Prevention, Atlanta). HPS cases and less serious infections with SNV in Colorado peaked between May and July, as shown in Figure 1.

\section{Detection of immunoglobulin G antibody to SNV}

Because hantavirus-rodent host relationships are generally highly species specific, we assumed that detection of IgG antibody in deer mice indicated either past or present infection with SNV (Calisher et al. 2009). Blood samples were tested by a standard enzyme-linked immunosorbent assay for IgG antibody to SNV (Feldmann et al. 1993). The broad crossreactivity of the nucleocapsid antigen of New World hanta-

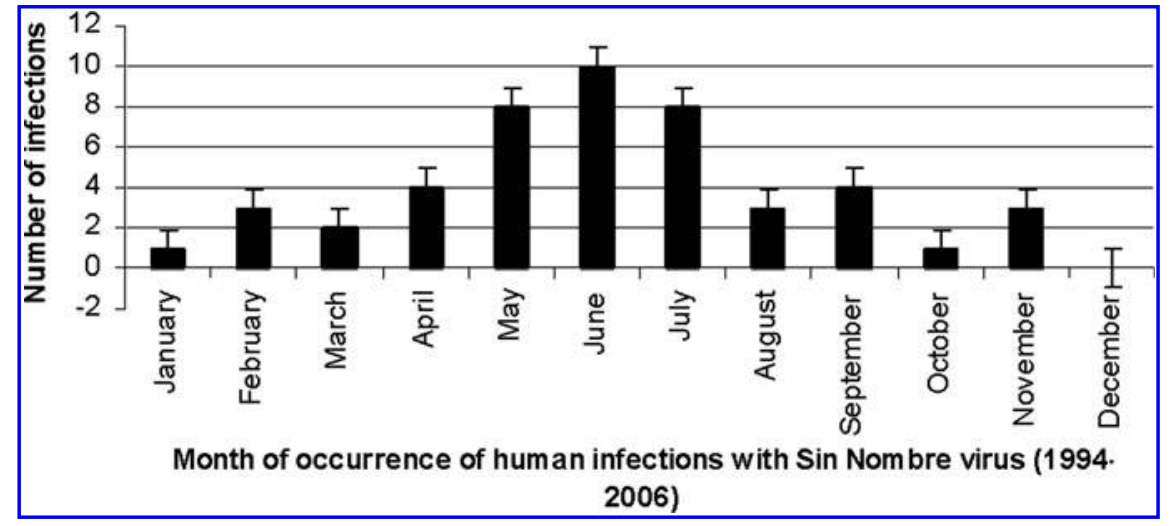

FIG. 1. Mean number of Sin Nombre virus infections in humans by month of occurrence, Colorado, 1994-2006. Bars are standard errors. 
viruses used in this test allows detection of antibody to SNV and closely related hantaviruses; the specific hantavirus can only be determined by detecting and sequencing of viral RNA, which we have done with multiple tissue samples from multiple seropositive deer mice captured at the Fort Lewis site and elsewhere (Black et al. 2009).

\section{Results}

Quarterly numbers of deer mice from June 1994 to October 2006 ranged from 0 to 333 (Fig. 2), with most occurring in the years 1998-2000 and 2003-2006, and a significant peak in the fall of 2004. Prevalences of deer mouse antibody to SNV also were high at certain periods during those years, ranging from $0 \%$ to $53 \%$; we discount the $60 \%$ prevalence in the second quarter of 1995 because we captured very few mice during that interval and that likely skewed the importance of the high antibody prevalence. Five human infections with SNV in La Plata County were documented during the period 1994-2006, two each in 1998 (onsets of illnesses in June and November) and 1999 (onsets of illnesses in June and July), and one in 2005 (onset of illness in March).

The occurrences of laboratory-confirmed HPS cases as well as other documented SNV infections of humans in La Plata County from 1994 to 2006 coincided roughly with considerable increases in both deer mouse population sizes and prevalence of antibody to SNV at the Fort Lewis site. The few instances in which the number of deer mouse captures was low but prevalences were high undoubtedly were the result of statistical aberrations due to sample sizes (i.e., $2 / 4=50 \%, 3$ / $5=60 \%$, etc.). When we examined the relationship between the number of deer mice and the number of infected deer mice, they were nearly identical (Fig. 3), the peaks of both numbers of rodents and number of antibody-positive rodents being essentially the same. Four of the human HPS cases di- agnosed in La Plata County occurred at about the period when rodent populations and numbers of antibody-positive deer mice were peaking in 1998 and 1999, and the other HPS case occurred just after similar peaks in 2005.

\section{Discussion}

As of December 2009, 537 confirmed HPS cases (casefatality rate $36 \%$ ) had been reported to the U.S. Centers for Disease Control and Prevention from 31 states (Levy et al. 2009). Between 1993 and 2006, 47 cases were recorded as being in Colorado residents who acquired their infections in Colorado; 5 of these were from La Plata County, for which Durango serves as the County seat. Clearly, statistical analyses of so few cases are difficult to conduct and the results may not be significant or may be inappropriate. Further, without parallel rodent studies in or nearer the town of Durango and throughout Colorado, there is no way to determine whether rodent populations and prevalence of antibody to SNV elsewhere are indicative of risk of acquisition of infection with SNV in Durango, La Plata County, or Colorado in general. Field studies of rodents and their infections with SNV usually are done in isolated and serene locations where such work can be done safely and distant from human disturbances. Few, if any such studies, have been done in areas with high human population densities, mainly because HPS is principally a disease of rural residents and because deer mice are much more common in rural areas. Nonetheless, our data suggest trends, which may be all that is possible for this relatively rare disease.

Antibody in deer mice is indicative of current or past infections, and may or may not be associated with persistent viral shedding (Calisher et al. 2009). The peaks in deer mouse populations and antibody prevalences we observed may have coincided with both peak transmission periods and

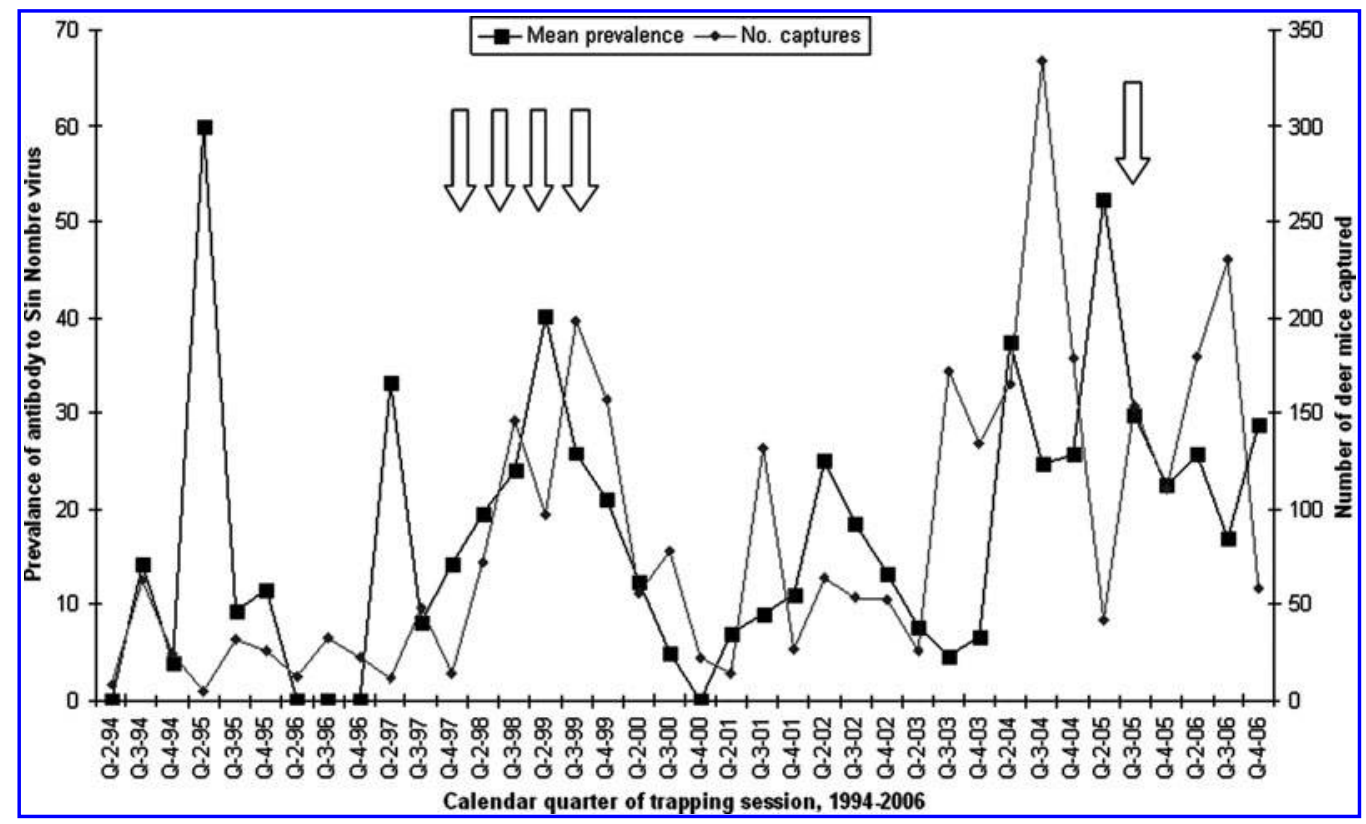

FIG. 2. Mean prevalence of IgG antibody to Sin Nombre virus and number of adult deer mice, Fort Lewis, Colorado, and human infections (arrows) with the virus in La Plata County towns and villages, Colorado, 1994-2006. 


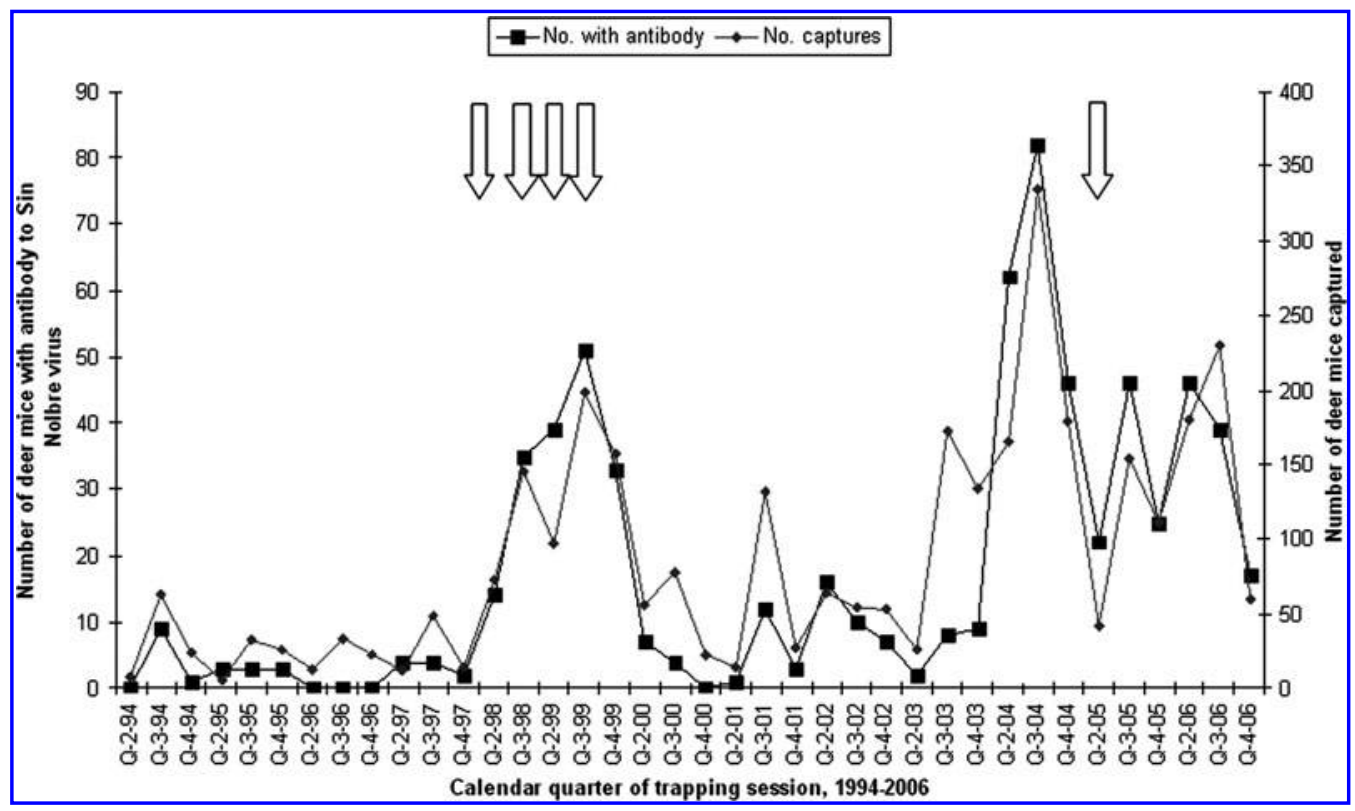

FIG. 3. Number of adult deer mice and number of those mice with antibody to Sin Nombre virus, Fort Lewis, Colorado, and human infections (arrows) with the virus in La Plata County towns and villages, Colorado, 1994-2006.

presence of increased SNV in the environment, and therefore may have increased the risk of human acquisition of SNV infection. Alternatively, it may be that the prevalence of virus in deer mice is not as important as the number of SNV-infected deer mice. If, for example, 2 of 10 (20\%) deer mice in a confined area, home A for instance, have antibody to SNV and both these rodents are shedding virus, and 10 of $100(10 \%)$ deer mice in home B have antibody to SNV and all 10 are shedding virus, there are five times as many deer mice shedding virus in home $\mathrm{B}$, even though the antibody prevalence in the rodents in home B is half what it is in home A. One could conclude from such an exercise that the critical number may be that of the size of the population of SNV-infected deer mice in the area, not of the prevalence of antibody to that virus. Whereas HPS cases and less serious infections with SNV in Colorado peak between May and July (Fig. 1), deer mouse population sizes usually peak in the fall. This also is the usual situation in other states in the western United States and in western Canada as well (unpublished data, courtesy of the U.S. Centers for Disease Control and Prevention and H. Artsob, National Microbiology Laboratory, Health Canada, Winnipeg, Manitoba).

SNV infections of humans from 1994 to 2006 were documented in 25 of Colorado's 64 counties. When one considers that Colorado, the eighth largest state in the United States (total area nearly 27 million hectares), is 24 th in population, it is clear that the statewide human population density is not high and is even lower when populations of the largest cities, where few if any HPS cases have been shown to occur, are removed from the equation. Thus, the likelihood of acquiring an SNV infection in Colorado is, in general, quite low. Cline et al. (2010) observed that most HPS cases in Montana have occurred in rural areas, as have most cases in the western United States as a whole. In Colorado, an incidence of 0.65 HPS cases per 100,000 humans has been estimated statewide, but the incidence in rural areas is more than six times higher, 4.19 per 100,000 humans (Douglass et al. 2005).

In summary, peak deer mouse populations and peak numbers of SNV-infected deer mice likely are interrelated and roughly associated with the occurrence of SNV infections of nearby humans. However, because human infections with SNV peak in late spring to early summer and deer mouse populations usually peak in the fall, it is likely that other factors create an increased risk for acquiring such infections, including human behaviors, such as entering and cleaning outbuildings unprotected from aerosols. Armstrong et al. (1995) and Zeitz et al. (1995) reported that HPS was associated with entering or cleaning rarely used structures or was associated with peridomestic cleaning, agricultural activities, and an increased number of small rodents in the household, and it was reported by Kuenzi et al. (2001) and Waltee et al. (2009) that seasonal dispersal patterns of recently infected sylvan deer mice indicate that they enter habitations and other buildings on rural properties.

Given the many variables contributing to or inhibiting the trophic cascade (Yates et al. 2002), including precipitation, temperature, and other meteorological events, rodent food availability, presence of predators, vegetation (for both rodent food and cover), variations in biodiversity (including presence of competitors), land use modifications, and other interdependent and independent variables, it is impossible at this time to accurately predict an increase in disease or infection in either humans or other vertebrates. At present, it appears that changes in the habitat variables may lead to increased rodent populations, which in turn lead to interspecific and intraspecific competition and agonistic behaviors, and thus to virus transmission (biting, scratching, exchange of infectious, excreta, etc.). Longitudinal studies of hantaviral ecology as well as of plague (Brown et al. 2010) and Lyme disease (Ostfeld et al. 2006) have advanced our understanding 
of the dynamics of the viruses and bacteria that cause these diseases, and we recognize that there are enormous complexities caused by the occurrence and interactions of multiple variables.

Studies of Puumala virus in its rodent reservoir hosts, bank voles (Myodes glareolus), in Sweden (Olsson et al. 2009) and Belgium (Tersago et al. 2008, 2010) have shown a relationship between the abundance of these rodents and the risk of human infections. Analysis of the relatively small data set presented here suggests that with regard to SNV and HPS, disease risk may be influenced as much by human activities as by ecologic variables, and that the more deer mice there are and the more SNV-infected deer mice there might then be, the higher the probability of human contact with the virus, and the higher the likelihood of HPS case occurrence. The takehome lesson is that risk of HPS may be appreciably decreased by strenuous avoidance of contact with deer mice and their excreta and, as our data parallel those from Europe with Puumala virus and bank voles, suggests that this host-virus relationship may be a general phenomenon regarding hantaviruses and human disease.

\section{Acknowledgments}

We are grateful to Elisabeth Lawaczeck, DVM, Colorado Department of Public Health and Environment, Denver, for providing human HPS case data, including month of onset, county of exposure, county of residence, and outcome of the case (whether died or survived). We also thank Arie Ponce Manangan, Health Scientist/Geospatial Analyst/ Geographer, Special Pathogens Branch, Division of Viral and Rickettsial Diseases, National Center for Zoonotic, VectorBorne, and Enteric Diseases, U.S. Centers for Disease Control and Prevention, Atlanta, Georgia, and John Pape, formerly of the Disease Control and Environmental Epidemiology Division, Colorado Department of Public Health and Environment, for providing summarized hantavirus infection data for humans in Colorado. The authors also are indebted to Richard J. Douglass, Montana Tech of Montana State University, Bozeman, Montana, and Harvey Artsob, National Microbiology Laboratory, Health Canada, Winnipeg, Manitoba, for allowing us to publish their unpublished data regarding Montana and western Canada, respectively, and for sharing with us their insightful observations. Funding for this work was provided by the U.S. Centers for Disease Control and Prevention, Atlanta, Georgia, under cooperative agreement no. U50/ccu809862-03.

\section{Disclosure Statement}

None of the authors has a commercial association that might create a conflict of interest in connection with this article.

\section{References}

Armstrong, LR, Zaki, SR, Goldoft, MJ, Todd, RL, et al. Hantavirus pulmonary syndrome associated with entering or cleaning rarely used, rodent-infested structures. I Infect Dis 1995; 172:1166.

Baars, DL. Navajo Country: A Geology and Natural History of the Four Corners Region. Albuquerque, NM: University of New Mexico Press, 1995:255.
Black, WC, Doty, JB, Hughes, MT, Beaty, BJ, et al. Temporal and geographic evidence for evolution of Sin Nombre virus using molecular analyses of viral RNA from Colorado, New Mexico and Montana. Virol J 2009; 6:102. Available at www .virologyj.com/content/6/1/102

Brown, HE, Ettestad, P, Reynolds, PJ, Brown, TL, et al. Climatic predictors of the intra- and inter-annual distributions of plague cases in New Mexico based on 29 years of animal-based surveillance data. Am J Trop Med Hyg 2010; 82:95-102.

Calisher, CH, Peters, CJ, Douglass, RJ, Kuenzi, AJ. Hantaviral infections of rodents: possible scenarios. Arch Virol 2009; 154 : 1195-1197.

Calisher, CH, Root, JJ, Mills, JN, Rowe, JE, et al. Epizootiology of Sin Nombre and El Moro Canyon hantaviruses, southeastern Colorado, 1995-2000. I Wildl Dis 2005; 41:1-11.

Calisher, CH, Sweeney, W, Mills, JN, Beaty, BJ. Natural history of Sin Nombre virus in western Colorado. Emerg Infect Dis 1999; 5:126-134.

Calisher, $\mathrm{CH}$, Wagoner, KD, Amman, BR, Root, J, et al. Demographic factors associated with prevalence of antibody to $\mathrm{Sin}$ Nombre virus in deer mice in the western United States. J Wildl Dis 2007; 43:1-11.

Childs, JE, Ksiazek, TG, Spiropoulou, CF, Krebs, JW, et al. Serologic and genetic identification of Peromyscus maniculatus as the primary rodent reservoir for a new hantavirus in the southwestern United States. J Infect Dis 1994; 169:1271-1280.

Cline, BJ, Carver, S, Douglass, R. Relationship of human behavior within outbuildings to potential exposure to Sin Nombre virus in Western Montana. EcoHealth 2010 [Epub ahead of print].

Douglass, RJ, Calisher, CH, Bradley, KC. State-by-state incidences of hantavirus pulmonary syndrome in the United States, 1993-2004. Vector Borne Zoonot Dis 2005; 5:189-192.

Feldmann, H, Sanchez, A, Morzunov, S, Spiropoulou, CF, et al. Utilization of autopsy RNA for the synthesis of the nucleocapsid antigen of a newly recognized virus associated with hantavirus pulmonary syndrome. Virus Res 1993; 30: 351-367.

Fitzgerald, JP, Meaney, CA, Armstrong, DM. Mammals of Colorado. Niwot, Colorado: University Press of Colorado, 1994:467.

Hughes, JM, Peters, CJ, Cohen, ML, Mahy, BW. Hantavirus pulmonary syndrome: an emerging infectious disease. Science 1993; 262:850-851.

Kuenzi, AJ, Douglass, RJ, White, D, Jr., Bond, CW, et al. Antibody to Sin Nombre virus in rodents associated with peridomestic habitats in west central Montana. Am J Trop Med Hyg 2001; 64:137-146.

Levy, C, Gains, K, Crocco, V, Brown, J, et al. Hantavirus pulmonary syndrome in five pediatric patients-four states, 2009. Morb Mortal Wkly Rep 2009; 58:1409-1412.

Olsson, GE, Hjertqvist, M, Lundkvist, A, Hornfeldt, B. Predicting high risk for human hantavirus infections, $\underline{\text { Sweden. Emerg }}$ Infect Dis 2009; 15:104-106.

Ostfeld, RS, Canham, CD, Oggenfuss, K, Winchcombe, RJ. Climate, deer, rodents, and acorns as determinants of variation in lyme disease risk. PLoS Biol 2006; 4:e145.

Tersago, K, Verhagen, R, Servais, A, Heyman, P, et al. Hantavirus disease (nephropathia epidemica) in Belgium: effects of tree seed production and climate. Epidemiol Infect 2008; 137:250-256.

Tersago, K, Verhagen, R, Vapalahti, O, Heyman, P, et al. Hantavirus outbreak in Western Europe: reservoir host infection dynamics related to human disease patterns. Epidemiol Infect 2010; 10:1-10. 
Waltee, D, Lonner, BN, Kuenzi, AJ, Douglass, RJ. Seasonal dispersal patterns of sylvan deer mice (Peromyscus maniculatus) within Montana rangelands. J Wildl Dis 2009; 45:998-1007.

Yates, TL, Mills, JN, Parmenter, RR, Ksiazek, TG, et al. The ecology and evolutionary history of an emergent disease: hantavirus pulmonary syndrome. Bioscience 2002; 52:989-998.

Zeitz, PS, Butler, JC, Cheek, JE, Samuel, MC, et al. A case-control study of hantavirus pulmonary syndrome during an outbreak in the southwestern United States. J Infect Dis 1995; 17:864-870.
Address correspondence to:

Charles H. Calisher

Arthropod-borne and Infectious Diseases Laboratory Department of Microbiology, Immunology, and Pathology College of Veterinary Medicine and Biomedical Sciences

Colorado State University Fort Collins, CO 80523

E-mail: calisher@cybersafe.net 